\title{
EXPERIMENTAL INVESTIGATION AND MULTI-GENE GENETIC PROGRAMMING SIMULATION OF PORTLAND CLINKER BURNABILITY
}

\author{
Vahab Ghalandari ${ }^{1}, H_{a m i d r e z a}$ Bagheri $^{2}$, Ali Mohebbi $^{2}, \otimes$, Hadi Esmaeili $^{2}$
}

https://doi.org/10.23939/chcht15.04.559

\begin{abstract}
In this study, the effect of chemical composition of the raw material on the clinker burnability was studied by determination of free $\mathrm{CaO}$ (wt \%) content of clinker. The burnability of two types of Portland clinker was investigated for silica modules of 2.3, 2.5 and 2.7 and lime saturation factor of $0.88-0.98$. In addition, using the Multi-gene genetic programming (MGGP) model, the burnability of clinker was predicted. The results of MGGP model indicated that the performance of the model for predicting the amount of free $\mathrm{CaO}(\mathrm{wt} \%$ ) was acceptable. Moreover, using MGGP, a promising correlation was introduced for accurately calculating the amount of free $\mathrm{CaO}$ (wt \%). The performance of this correlation was compared with FL-Smidth, and it was established that the average errors of MGGP correlation and FL-Smidth equation were 2.95 and $7.45 \%$, respectively.
\end{abstract}

Keywords: multi-gene genetic programming, burnability, free $\mathrm{CaO}$, Portland clinker, correlation.

\section{Introduction}

The main component of concrete is Portland cement, which is widely used around the world. It is a fine and hydraulic substance that is manufactured in the ball mill by grinding gypsum and Portland clinker. Portland clinker consists of four major phases including alite $\left(3 \mathrm{CaO} \cdot \mathrm{SiO}_{2}\right), \quad$ belite $\left(2 \mathrm{CaO} \cdot \mathrm{SiO}_{2}\right), \quad$ aluminate $\left(3 \mathrm{CaO} \cdot \mathrm{Al}_{2} \mathrm{O}_{3}\right)$, ferrite $\left(4 \mathrm{CaO} \cdot \mathrm{Al}_{2} \mathrm{O}_{3} \cdot \mathrm{Fe}_{2} \mathrm{O}_{3}\right)$ and also some minor components. The raw meal of clinker consists of some mineral materials including $\mathrm{SiO}_{2}, \mathrm{CaO}, \mathrm{Fe}_{2} \mathrm{O}_{3}$, $\mathrm{Al}_{2} \mathrm{O}_{3}, \mathrm{MgO}$, and some other minor components such as sodium, potassium, chlorine, fluorine, and titanium. The clinker is formed by burning the raw material (kiln feed) at high temperatures (about $1723 \mathrm{~K}$ ) in a rotary kiln. A

\footnotetext{
${ }^{1}$ Kerman Momtazan Cement Company, Kerman, Iran

${ }^{2}$ Department of Chemical Engineering, Faculty of Engineering,

Shahid Bahonar University of Kerman, Kerman, Iran

amohebbi2002@yahoo.com,amohebbi@uk.ac.ir

(c) Ghalandari V., Bagheri H., Mohebbi A., Esmaeili H., 2021
}

thorough comprehension of the effect of physical and chemical features of raw material (chemistry, uniformity, fineness, and mineralogy) on the clinkerization process is the main basis for reducing expenses, growing production, and enhancing the quality of clinker in the cement factories [1-3].

Some investigations have been done focusing on the impact of minor components on the clinker burnability. These works have investigated the impacts of minor components on the reactivity and consistency of main phases of clinker, mineralogy of the clinker ingredients, and clinker formation procedure. It has been observed that the formation of alite phase is enhanced by some materials like $\mathrm{F}, \mathrm{Cr}, \mathrm{Cu}, \mathrm{Zn}, \mathrm{MgO}$, and $\mathrm{TiO}_{2}$ in the sintering process. Actually, these materials reduce the burning temperature of the clinker and facilitate the reaction of free $\mathrm{CaO}$ and belite phase [4-12].

Boughanmi et al. [13] studied the influence of natural fluorapatite on the clinker burning process. They showed that the use of natural fluorapatite could improve the burnability of clinker when the amount of alite is low in the clinker composition. Therefore, it could neutralize the harmful effect of phosphate on the conversion of belite and $\mathrm{CaO}$ in alite. Shang et al. [14] investigated the effect of titanium on the formation of clinker phases. It was studied by different instrumental analysis methods including XRD, NMR and SEM-EDS. The results demonstrated that $\mathrm{TiO}_{2}$ could improve the formation of alite phase by changing the aluminate and ferrite phases and also by reducing the value of viscosity of liquid phase in the process of clinker burning. Kolovos et al. [15] studied the influence of sulfur and phosphorus on the sintering reactions. The results showed that these mineral elements could improve the burnability of the clinker because they are significantly dissolved in the liquid phase in the sintering zone of the rotary kiln. Therefore, phosphorus could stabilize the beta polymorph of belite $\left(\beta-\mathrm{C}_{2} \mathrm{~S}\right)$, which could lead to increase in the amount of free $\mathrm{CaO}$ in clinker composition. Zhao et al. [16] investigated the effect of $\mathrm{MgO}, \mathrm{BaO}$ and $\mathrm{SO}_{3}$ on formation of belite during the clinkerization process. The 
results demonstrated that these mineral elements could significantly promote the formation of belite phase by reducing the amount of free $\mathrm{CaO}$ in the $\mathrm{C}_{2} \mathrm{~S}$ composition. Computer simulation was used widely for predicting the behavior of various complex chemical systems in different industries [17-23]. Some researchers investigated the issue of the cement raw material mixing, using computer modelling. Bavdaz and Kocijan [24] presented a novel method of the fuzzy controller on the basis of the progressive algorithm by using MATLAB software to control the process of raw material preparation. Pani et al. [25] used an artificial neural network (ANN) to predict the clinker properties. They investigated the back propagation (BP) and the radial basis networks (RBNs); according to the results, the first network had better performance than the second one.

Multi-gene genetic programming (MGGP) has shown a pivotal ability in predicting the engineering properties. Generally, MGGP is a type of genetic programming (GP), which tries to co-use the model structure selection ability of GP with the parameter estimation ability of classical regression to be able to capture nonlinear interactions [26]. It should be noted that GP is an evolutionary algorithm-based technique, which is based on a biological evolution to find computer programs that perform a specific user-defined task. As an optimization technique, GP is a machine learning technique, which is used to optimize a population of computer programs based on a fitness landscape to perform a given computational task [27, 28].

The burnability of clinker is an important process in cement factories due to its effect on the clinker burning in rotary kiln and the consumption of thermal energy. In this study, for the first time the burnability of clinker was studied experimentally and then it was investigated theoretically. Burning process of two industrial types of Portland clinker was performed in an electrical furnace at various chemical composition modules. For the simulation of the process, for the first time, the MGGP was used to predict the clinker burnability.

\section{Experimental}

\subsection{Theory}

In a cement plant, raw materials are ground together to create a kiln feed with very fine particles. The size of $99 \%$ of these particles is smaller than $90 \mu \mathrm{m}$. The clinker type depends largely on the chemical composition of the kiln feed. Main modules are widely utilized in cement factories to outline the chemical composition of the kiln feed as LSF, SM and AM [29]:

$$
\begin{gathered}
\mathrm{LSF}=\mathrm{wt} \% \mathrm{CaO} / 2.8\left(\mathrm{wt} \% \mathrm{SiO}_{2}\right)+ \\
+1.2\left(\mathrm{wt} \% \mathrm{Al}_{2} \mathrm{O}_{3}\right)+0.65\left(\mathrm{wt} \% \mathrm{Fe}_{2} \mathrm{O}_{3}\right) \\
\mathrm{SM}=\mathrm{wt} \% \mathrm{SiO}_{2} /\left(\mathrm{wt} \% \mathrm{Al}_{2} \mathrm{O}_{3}+\mathrm{wt} \% \mathrm{Fe}_{2} \mathrm{O}_{3}\right) \\
\mathrm{AM}=\mathrm{wt} \% \mathrm{Al}_{2} \mathrm{O}_{3} / \mathrm{wt} \% \mathrm{Fe}_{2} \mathrm{O}_{3}
\end{gathered}
$$

where silica module (SM) controls the portion of silicate phase and the lime saturation factor (LSF) primarily determines the proportion of the alite phase $\left(3 \mathrm{CaO} \cdot \mathrm{SiO}_{2}\right)$ to belite phase $\left(2 \mathrm{CaO} \cdot \mathrm{SiO}_{2}\right)$ in the clinker. For kiln feed preparation, LSF is adjusted in the range of $0.90-0.98$ to limit the quantity of free $\mathrm{CaO}$ that are not combined in main phases of Portland clinker. The alumina module (AM) determines the amount of melt phase which is necessary for the formation of alite. It is obtained from the reaction between free $\mathrm{CaO}$ and belite in the rotary kiln and mainly controls the aluminate phase $\left(3 \mathrm{CaO} \cdot \mathrm{Al}_{2} \mathrm{O}_{3}\right)$ to ferrite phase $\left(4 \mathrm{CaO} \cdot \mathrm{Al}_{2} \mathrm{O}_{3} \cdot \mathrm{Fe}_{2} \mathrm{O}_{3}\right)$ ratio.

Nowadays, most of the cement factories use a method of calculating the clinker mineral composition that was presented by Bogue [30]. In this method, the composition is computed from the oxides composition of the clinker, based on the molecular weights of the oxides. The Bogue equations are as follow (if $\mathrm{AM}>=0.64$ ):

$$
\begin{gathered}
\mathrm{C}_{3} \mathrm{~S}=4.07(\mathrm{wt} \% \mathrm{CaO})-\left[7.60\left(\mathrm{wt} \% \mathrm{SiO}_{2}\right)+\right. \\
+6.71\left(\mathrm{wt} \% \mathrm{Al}_{2} \mathrm{O}_{3}\right)+1.43\left(\mathrm{wt} \% \mathrm{Fe}_{2} \mathrm{O}_{3}\right)+ \\
\left.+2.85\left(\mathrm{wt}_{0} \% \mathrm{SO}_{3}\right)\right] \\
\mathrm{C}_{2} \mathrm{~S}=2.867 \mathrm{wt} \%\left(\mathrm{SiO}_{2}\right)-0.754 \mathrm{wt} \%\left(\mathrm{C}_{3} \mathrm{~S}\right) \\
\mathrm{C}_{3} \mathrm{~A}=2.65 \mathrm{wt} \% \mathrm{Al}_{2} \mathrm{O}_{3}-1.692 \mathrm{wt} \% \mathrm{Fe}_{2} \mathrm{O}_{3} \\
\mathrm{C}_{4} \mathrm{AF}=3.043 \mathrm{wt} \% \mathrm{Fe}_{2} \mathrm{O}_{3}
\end{gathered}
$$

This is a mathematical method, which determines the amount of mineral composition of the clinker, approximately. Some methods like microscopy or X-ray diffraction should be utilized to evaluate the actual amount of clinker mineralogy, besides the Bogue method.

Principally, for Portland clinker the SM and AM are in the ranges of 1.9-3.2 and 1.0-2.5, respectively. Changing the lime saturation factor, silica module and alumina module can substantially vary the burnability of clinker, which is characterized by the ease of incorporating $\mathrm{C}_{2} \mathrm{~S}$ and free $\mathrm{CaO}$ into $\mathrm{C}_{3} \mathrm{~S}$. The clinker burnability can be influenced by various other variables, such as amount of the trace components, particle size of the kiln feed and mineralogy of ingredients. It is normally indicated by the amount of free $\mathrm{CaO}$ content in the composition of clinker.

There are various equations used to determine the reactivity of a kiln feed. One of the most important equations is proposed by FL-Smidth Company [29]:

$$
\begin{gathered}
\mathrm{CaO}_{1673 \mathrm{~K}}=[0.343(100 \mathrm{LSF}-93)+2.74(\mathrm{SM}-2.3)]+ \\
+\left[0.83 \mathrm{Q}_{45}+0.10 \mathrm{C}_{125}+0.39 \mathrm{R}_{45}\right]
\end{gathered}
$$

where $\mathrm{CaO}_{1673 \mathrm{~K}}$ is the free lime after burning for $30 \mathrm{~min}$ at $1673 \mathrm{~K}, \mathrm{Q}_{45}$ is the percent of quartz grains larger than $45 \mu \mathrm{m}, \mathrm{C}_{125}$ is the percent of calcite grains larger than $125 \mu \mathrm{m}$ and $\mathrm{R}_{45}$ is the percent of other acid-insoluble minerals larger than $45 \mu \mathrm{m}$. 
The FL-Smidth equation cannot give a correct estimation of free $\mathrm{CaO}$ of clinker. In fact, it can give knowledge about the effect of chemical and physical properties of kiln feed on the clinker burnability.

The initial part of the FL-Smidth equation indicates the chemical properties portion of the kiln feed. The LSF and SM indicate the amount of calcium oxide and silicate of the kiln feed, respectively. In the sintering zone of the rotary kiln, the quantity of liquid phase relates to the amount of SM; reducing the amount of SM leads to increase in the quantity of liquid phase, which can improve the burnability of clinker in the sintering zone of the rotary kiln.

The next part of the FL-Smidth equation indicates the physical properties portion of the kiln feed. The fineness and mineralogy of the kiln feed are demonstrated by the number of large particles including the quartz grains $\left(\mathrm{Q}_{45}\right)$, calcite grains $\left(\mathrm{C}_{125}\right)$ and other acid-insoluble minerals $\left(\mathrm{R}_{45}\right)$. Grindability of materials strongly depends on their chemical and physical properties. Therefore, variation in the kiln feed mineralogy can lead to different size portions of the kiln feed. For instance, when there are high amounts of quartz grains in the raw material, the grinding of $\mathrm{SiO}_{2}$ will be difficult; hence, the finer portion is usually lower than the larger portion of the kiln feed. The quartz particles in kiln feed have a negative effect on the burning conditions in the rotary kiln and may increase the amount of free $\mathrm{CaO}$ of clinker.

\subsection{Materials and Methods}

The kiln feed was prepared by blending $100 \mathrm{~g}$ of raw materials and grinding them into the fine materials. After adding some water, the kiln feed converted to small balls and dried on a platinum dish at $383 \mathrm{~K}$ for $30-60 \mathrm{~min}$ in an electrical oven. The burnability experimental tests were performed according to FL-Smidth method (the burnability experimental method for clinker in cement factories), and each experiment was repeated twice to verify the data. The temperature of electrical furnace (RHF 16/8 model, Carbolite Company, United Kingdom) was set at $1223 \mathrm{~K}$ for $5 \mathrm{~min}$ and $1673 \mathrm{~K}$ for $30 \mathrm{~min}$, then the clinkers were cooled in a desiccator. The clinkers were ground into powder in a lab mill to obtain a residue of $\sim 5 \mathrm{wt} \%$ on the $0.04 \mathrm{~mm}$ standard screen. After dissolving one gram of clinker powder in ethylene glycol, the amount of free $\mathrm{CaO}$ was obtained by titration in the laboratory. In addition, the chemical composition of the clinker was determined by XRF (Cubix model, Panalytical Company, Netherlands). The chemical composition of the raw material is given in Table 1 . Moreover, Figs. 1-3 show the flow diagram of the methodology of experimental tests, particle size distribution of kiln feed and microscopic view of clinker sample, respectively.

Table 1

The chemical composition of the raw material (wt \%)

\begin{tabular}{|c|c|c|c|c|c|c|c|c|c|c|c|}
\hline Compound & L.O.I & $\mathrm{SiO}_{2}$ & $\mathrm{Al}_{2} \mathrm{O}_{3}$ & $\mathrm{Fe}_{2} \mathrm{O}_{3}$ & $\mathrm{CaO}$ & $\mathrm{MgO}$ & $\mathrm{K}_{2} \mathrm{O}$ & $\mathrm{Na}_{2} \mathrm{O}$ & $\mathrm{TiO}_{2}$ & $\mathrm{SO}_{3}$ & $\mathrm{Cl}$ \\
\hline Lime stone & 42.20 & 4.10 & 1.20 & 0.60 & 50.10 & 1.20 & 0.20 & 0.07 & - & 0.02 & - \\
\hline Clay & 36.20 & 39.20 & 7.20 & 3.50 & 8.20 & 1.70 & 1.80 & 0.80 & 0.40 & 0.90 & 0.012 \\
\hline Iron Ore & 19.10 & 4.10 & 2.60 & 49.30 & 21.20 & 2.30 & 0.51 & 0.11 & - & 0.21 & 0.008 \\
\hline Bauxite & 12.40 & 28.00 & 33.20 & 19.90 & 0.81 & 0.37 & 1.19 & 0.10 & 3.56 & 0.48 & - \\
\hline
\end{tabular}

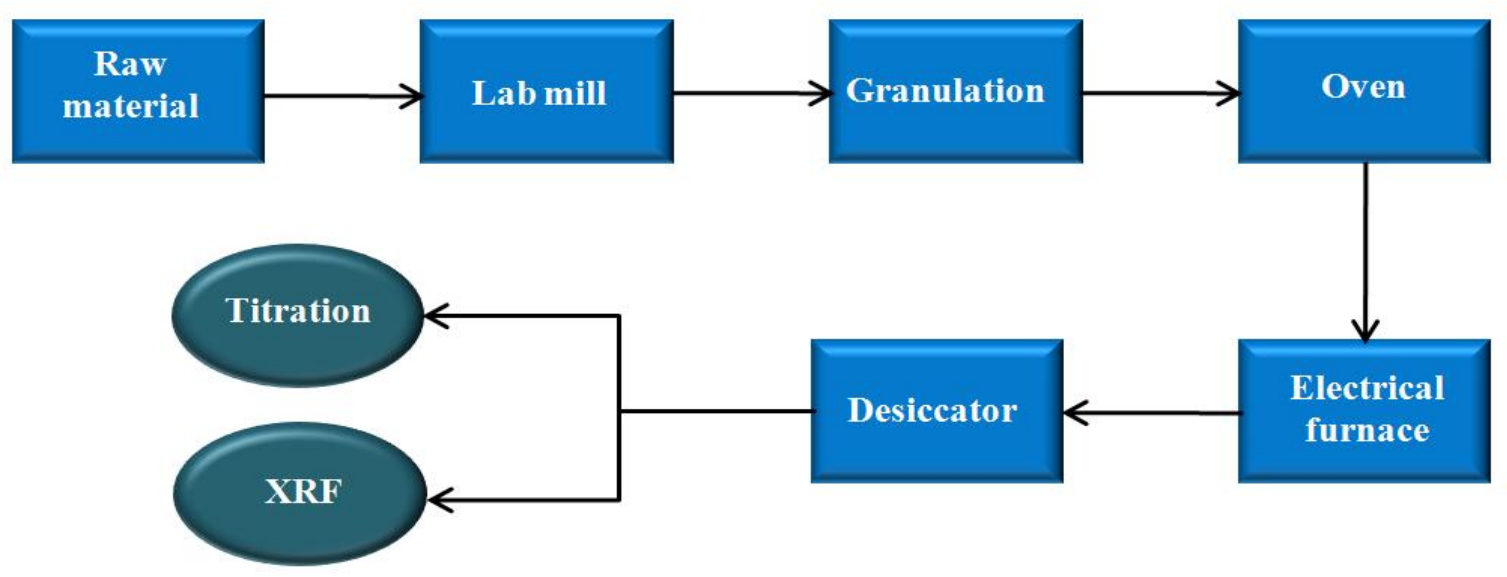

Fig. 1. Flow diagram of the methodology of experimental tests 

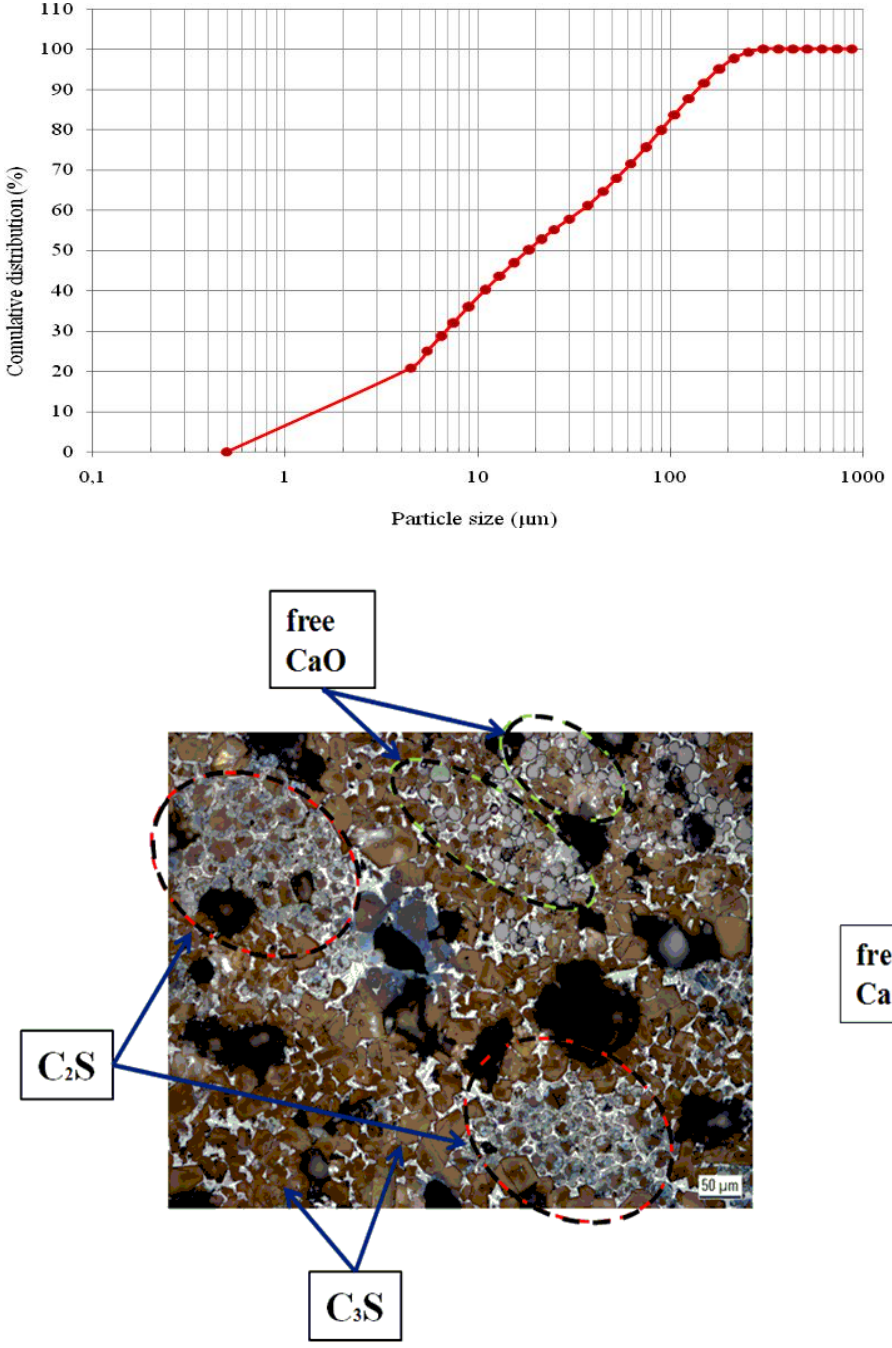

Fig. 2. The particle size distribution of kiln feed $\left(\mathrm{Q}_{45}=3.2 \%\right.$ (the percent of quartz grains larger than $45 \mu \mathrm{m}$ ), $\mathrm{C}_{125}=3.5 \%$ (the percent of calcite grains larger than $125 \mu \mathrm{m}$ ) and $\mathrm{R}_{45}=2.2 \%$ (the percent of other acid-insoluble minerals larger than $45 \mu \mathrm{m})$; density $=3.2 \mathrm{~g} / \mathrm{cm}^{3}$ )

Fig. 3. Microscopic view of the clinker sample $(\mathrm{LSF}=0.95, \mathrm{SM}=2.7$ and $\mathrm{AM}=1.4)$.

Diffuse nests of belite and free $\mathrm{CaO}$ beside alite.

\section{Results and Discussion}

\subsection{Experimental Data}

The burnability experimental data of two types of Portland clinker ( $\mathrm{PC} 1$ and $\mathrm{PC} 2$ ) were determined. The results are presented in Table 2 . In a cement factory, $\mathrm{PC} 1$ with $\mathrm{AM}=1$ and $\mathrm{PC} 2$ with $\mathrm{AM}=1.4$ are used to produce Type V and Type II Portland cement, respectively. These types of cement have a good resistance against attacking sulfates because the amount of the $\mathrm{C}_{3} \mathrm{~A}$ phase is low in their composition. It can be found in Table 2 that the maximum free $\mathrm{CaO}$ was observed at LSF of 0.98 and SM of 2.7. The amounts of maximum free lime were 8.11 and $7.14 \mathrm{wt} \%$ for $\mathrm{PC} 1$ and $\mathrm{PC} 2$, respectively. In addition, when the LSF was increased a higher free $\mathrm{CaO}$ was obtained. This was due to increasing the amount of $\mathrm{C}_{3} \mathrm{~S}$ and decreasing the amount of $\mathrm{C}_{2} \mathrm{~S}$ in clinker composition.

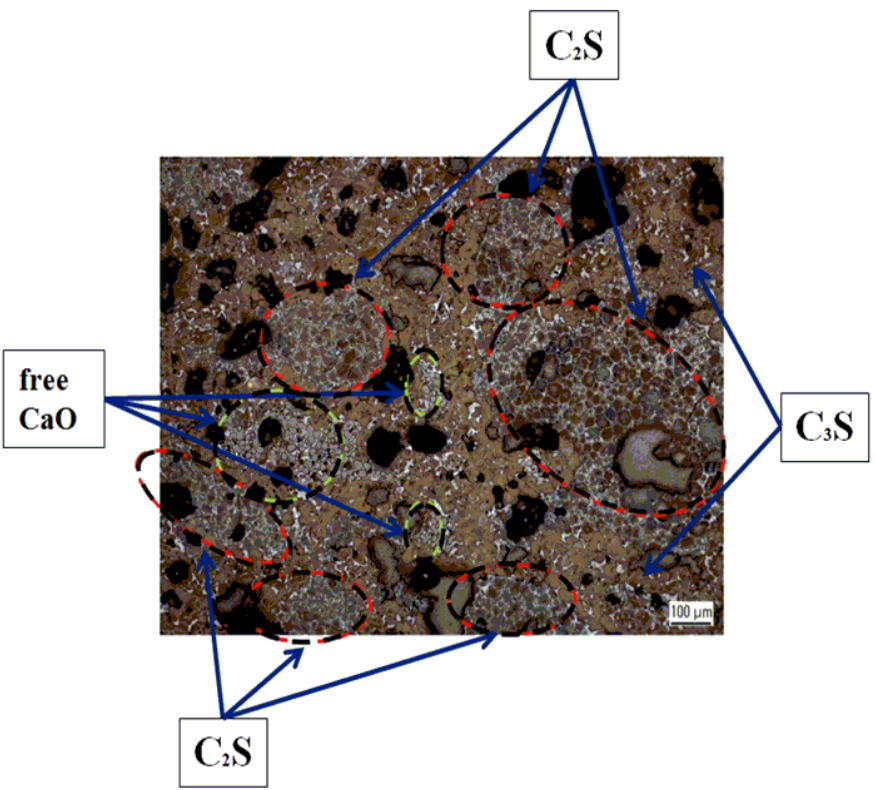

Actually, the chemical reactions between $\mathrm{SiO}_{2}$ and $\mathrm{CaO}$ lead to the formation of $\mathrm{C}_{2} \mathrm{~S}$; therefore, increasing the molar ratio of $\mathrm{CaO} / \mathrm{SiO}_{2}$ leads to the reduction of $\mathrm{C}_{2} \mathrm{~S}$ amount in the clinker composition. To produce $\mathrm{C}_{3} \mathrm{~S}$ from $\mathrm{C}_{2} \mathrm{~S}$ and free $\mathrm{CaO}$, the temperature should be increased above $1523 \mathrm{~K}$; therefore, the high quantity of energy is required. Actually, the increase in the LSF causes the clinker to burn harder and also increases the total potential $\mathrm{C}_{3} \mathrm{~S}$ content; therefore, the extent of $\mathrm{C}_{3} \mathrm{~S}$ in sintering zone is decreased and the clinker nodulisation is reduced. In addition, the consumption of thermal energy increases and as a result, the temperature of the sintering zone and the length of maximum temperature zone increase.

Moreover, when the $\mathrm{SM}$ decreases, less free $\mathrm{CaO}$ is obtained because the amount of $\mathrm{C}_{3} \mathrm{~S}$ and $\mathrm{C}_{2} \mathrm{~S}$ phases decreases as compared to the amount of $\mathrm{C}_{3} \mathrm{~A}$ and $\mathrm{C}_{4} \mathrm{AF}$ phases in clinker composition. The amount of later phases $\left(\mathrm{C}_{3} \mathrm{~A}\right.$ and $\left.\mathrm{C}_{4} \mathrm{AF}\right)$ determines the amount of melt phase at 
the burning temperature that is necessary for forming the clinker and improving the quality of physical and chemical properties of the cement product. Subsequently, when the SM increases, the amount of liquid phase at burning temperature decreases; thus, the energy consumption of burning of the clinker increases.

According to the results, the burnability of clinker was a function of the AM, but this dependency was not considered in FL-Smidth equation. The increase in the AM leads to the formation of lower quantity of liquid phase at a higher temperature; consequently, the clinker nodulation decreases. Variation in the AM does not have any effect on the formation of $\mathrm{C}_{3} \mathrm{~S}$. The chemical reaction between $\mathrm{C}_{3} \mathrm{~A}$ and $\mathrm{Fe}_{2} \mathrm{O}_{3}$ leads to the formation of $\mathrm{C}_{4} \mathrm{AF}$. $\mathrm{PC} 1$ had a higher amount of $\mathrm{Fe}_{2} \mathrm{O}_{3}$ than that of $\mathrm{PC} 2$ and it needs more energy to form $\mathrm{C}_{4} \mathrm{AF}$. Therefore, the energy consumption for clinker burning increases. As it can be seen from Table 2, the burnability of PC2 is more than that of $\mathrm{PC} 1$, subsequently; the $\mathrm{PC} 2$ with higher $\mathrm{AM}$ gives a lower amount of free $\mathrm{CaO}$.

Table 2

The experimental data of burnability for PC1 and PC2

\begin{tabular}{|c|c|c|c|}
\hline \multirow[t]{2}{*}{ LSF } & \multirow[t]{2}{*}{ SM } & \multicolumn{2}{|c|}{ Free $\mathrm{CaO}$, wt \% } \\
\hline & & $\mathrm{PC} 1$ with $\mathrm{AM}=1$ & $\mathrm{PC} 2$ with $\mathrm{AM}=1.4$ \\
\hline 0.88 & 2.3 & 2.15 & 2.09 \\
\hline 0.89 & 2.3 & 2.70 & 2.40 \\
\hline 0.90 & 2.3 & 3.09 & 2.69 \\
\hline 0.91 & 2.3 & 3.20 & 3.18 \\
\hline 0.92 & 2.3 & 3.73 & 3.71 \\
\hline 0.93 & 2.3 & 4.11 & 3.85 \\
\hline 0.94 & 2.3 & 4.32 & 4.23 \\
\hline 0.95 & 2.3 & 4.97 & 4.86 \\
\hline 0.96 & 2.3 & 5.47 & 5.21 \\
\hline 0.97 & 2.3 & 5.90 & 5.94 \\
\hline 0.98 & 2.3 & 6.61 & 6.10 \\
\hline 0.88 & 2.5 & 2.49 & 2.34 \\
\hline 0.89 & 2.5 & 3.00 & 2.70 \\
\hline 0.90 & 2.5 & 3.38 & 3.09 \\
\hline 0.91 & 2.5 & 3.71 & 3.31 \\
\hline 0.92 & 2.5 & 4.40 & 3.87 \\
\hline 0.93 & 2.5 & 4.71 & 4.02 \\
\hline 0.94 & 2.5 & 5.30 & 4.68 \\
\hline 0.95 & 2.5 & 5.40 & 5.14 \\
\hline 0.96 & 2.5 & 5.98 & 5.66 \\
\hline 0.97 & 2.5 & 6.51 & 6.52 \\
\hline 0.98 & 2.5 & 7.24 & 6.85 \\
\hline 0.88 & 2.7 & 3.01 & 2.81 \\
\hline 0.89 & 2.7 & 3.35 & 3.31 \\
\hline 0.90 & 2.7 & 3.90 & 3.47 \\
\hline 0.91 & 2.7 & 4.05 & 3.99 \\
\hline 0.92 & 2.7 & 4.90 & 4.20 \\
\hline 0.93 & 2.7 & 5.25 & 4.72 \\
\hline 0.94 & 2.7 & 5.90 & 5.08 \\
\hline 0.95 & 2.7 & 6.01 & 5.33 \\
\hline 0.96 & 2.7 & 6.71 & 6.35 \\
\hline 0.97 & 2.7 & 7.01 & 6.61 \\
\hline 0.98 & 2.7 & 8.11 & 7.14 \\
\hline
\end{tabular}

Table 3

The properties of used MGGP

\begin{tabular}{|c|c|c|c|c|}
\hline Population size & Tournament size & Tree depth & Max gene depth & Fitness function \\
\hline 200 & 8 & 3 & 3 & regressmulti_fitfun \\
\hline
\end{tabular}




\subsection{MGGP Model}

In this work MGGP, that is one of the most powerful techniques of soft computing, was used to train a network for predicting free $\mathrm{CaO}(\mathrm{wt} \%)$. The first step was to find the parameters that have the most effect on free $\mathrm{CaO}$ (wt \%). Therefore, a sensitive analysis method, Pearson method, was applied to determine the effect of important parameters on free $\mathrm{CaO}(\mathrm{wt} \%)$. The effects of LSF, SM and AM on free $\mathrm{CaO}$ (wt \%) were determined and the results are shown in Fig. 4. Hence, LSF, SM and AM were used as the input parameters of MGGP, while free $\mathrm{CaO}(\mathrm{wt} \%)$ was the output parameter.

The MGGP properties of training a simple but reliable configuration for MGGP used in this study are provided in Table 3. As shown in this Table, tree depth and max gene depth were selected based on the simplest choices.

On top of that, by applying MGGP, a correlation was obtained for free $\mathrm{CaO}$ (wt \%). Precisions of the network and the correlation were 99.19 and 99.10, respectively. As it can be seen in Fig. 5, actual and predicted values of free $\mathrm{CaO}(\mathrm{wt} \%)$ for training and testing of the MGGP network are illustrated. The obtained correlation for calculating free $\mathrm{CaO}\left(\mathrm{wt}^{\%} \%\right)$ is as follows:

$$
\begin{gathered}
\text { free } \mathrm{CaO}=\frac{4.811 e^{L S F}}{\cos (L S F)}+5.074 \sin (L S F) \cdot(A M-6.016)+ \\
+\frac{3.19 S M \cdot L S F^{2}}{A M}-2.265
\end{gathered}
$$

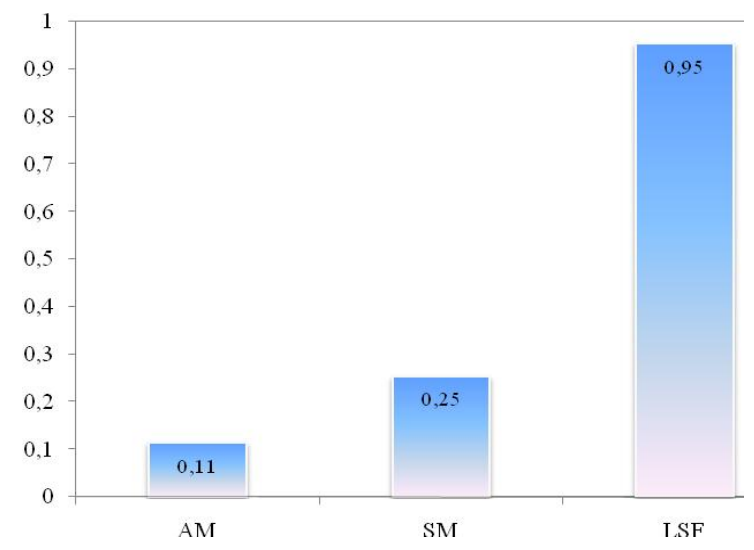

Fig. 4. Pearson sensitivity analysis for determining the effects of important parameters on free $\mathrm{CaO}$ (wt \%)
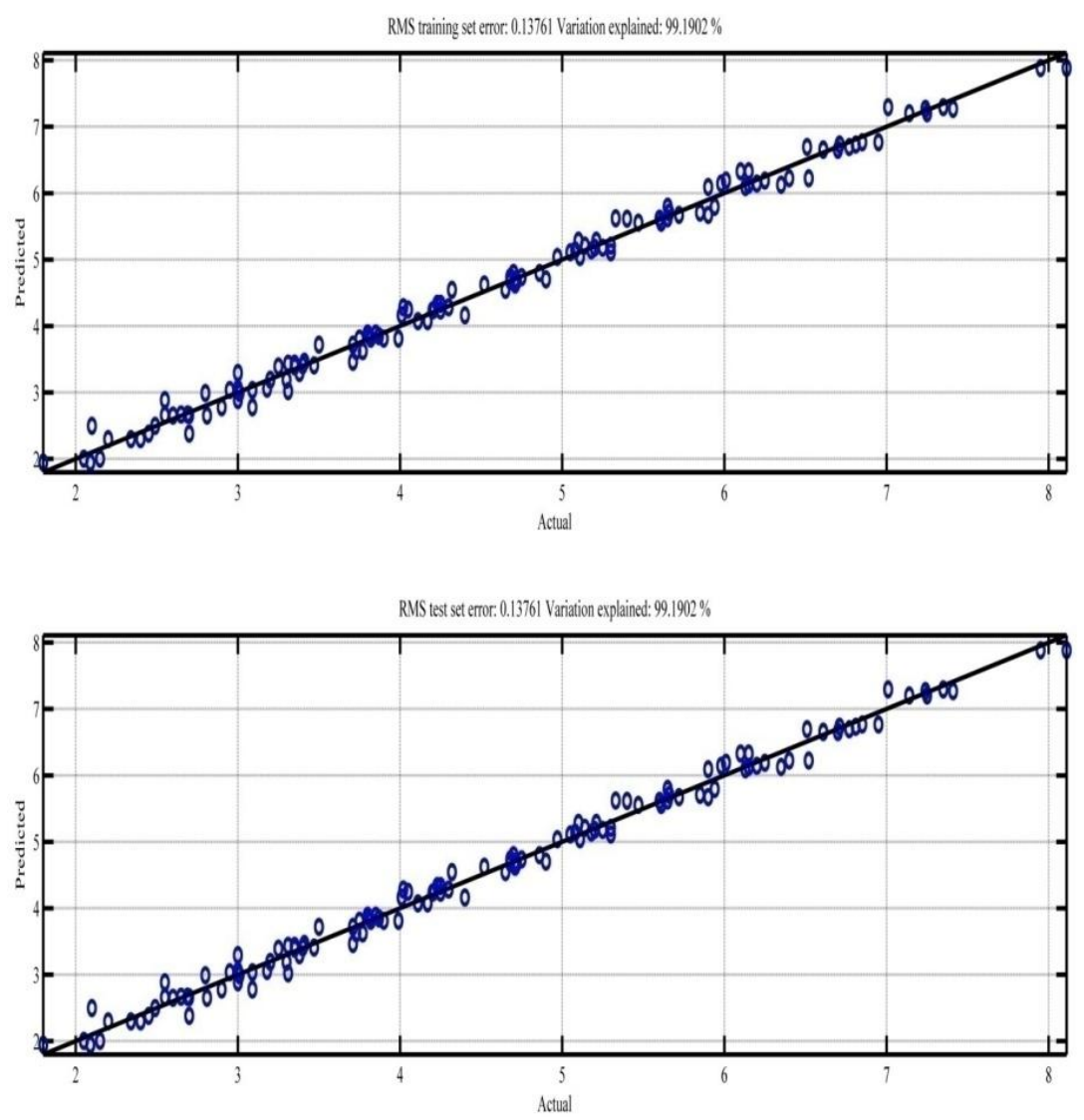

Fig. 5. Predicted $v s$. actual values of free $\mathrm{CaO}(\mathrm{wt} \%)$ for training and testing network, respectively 


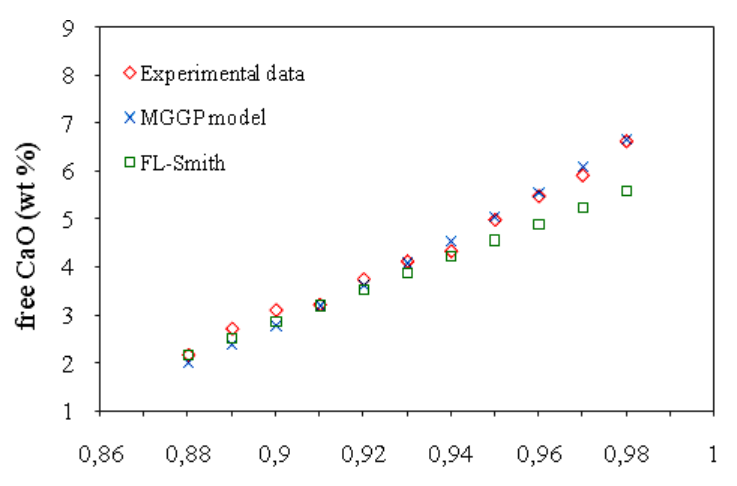

Lime saturation factor (LSF), SM=2.3
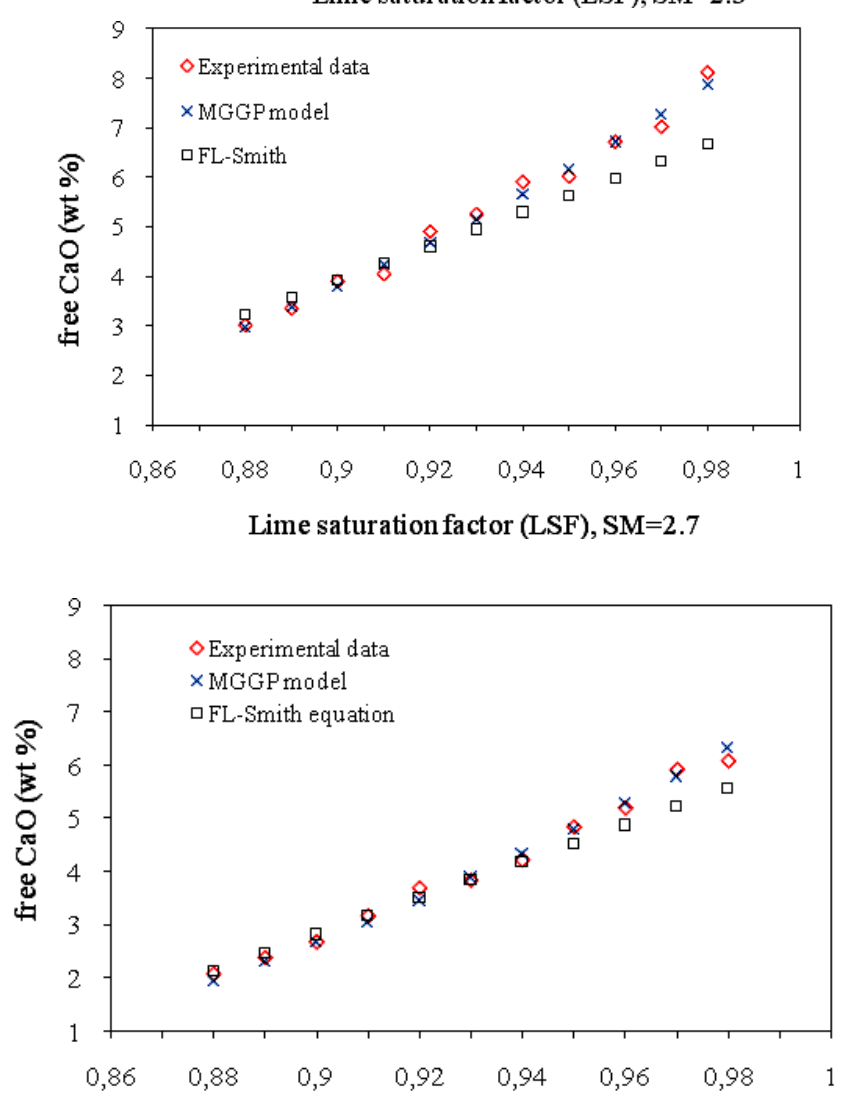

Lime saturation factor (LSF), SM=2.3

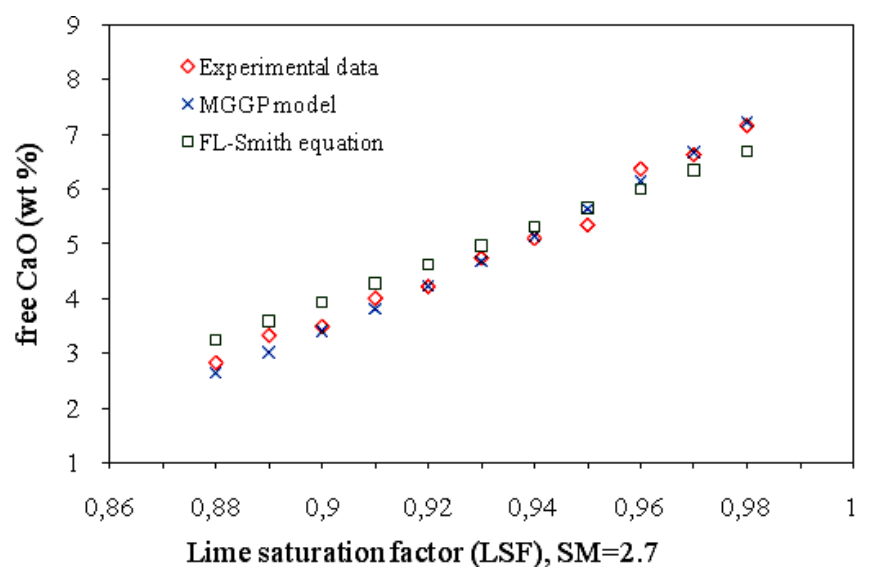

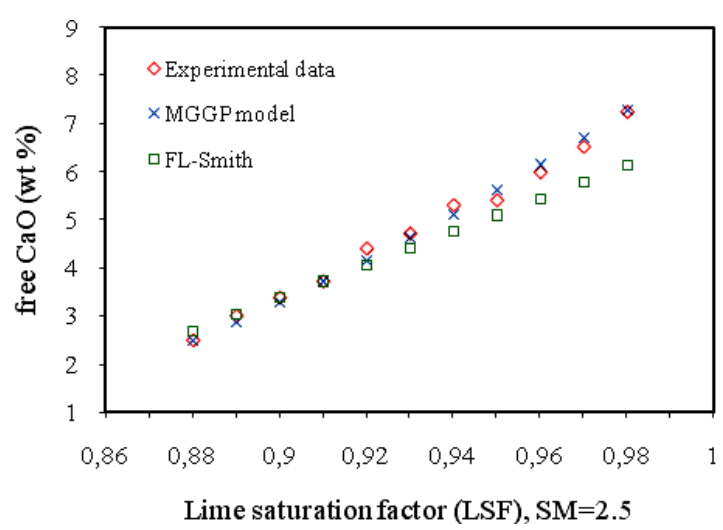

Fig. 6. Comparison of experimental data and simulated results for the burnability of $\mathrm{PC} 1$ with $\mathrm{AM}=1$

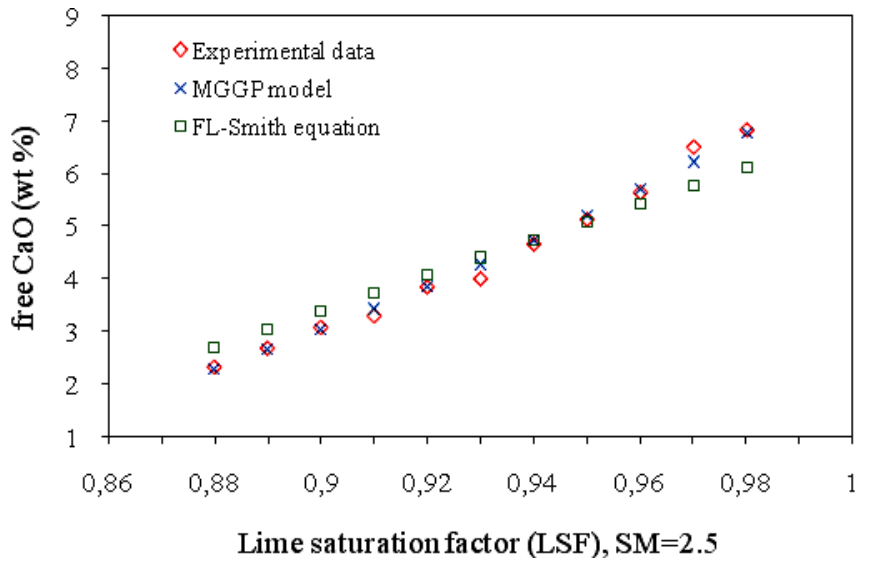

Fig. 7. Comparison of experimental data and simulated results for the burnability of $\mathrm{PC} 2$ with $\mathrm{AM}=1.4$ 
The results of MGGP correlation (Eq. (9)) and FLSmidth equation (Eq. (8)) as well as experimental data are compared in Figs. 6 and 7. It can be seen that both MGGP and FL-Smidth equations are in a good agreement with the experimental data. The average error of MGGP equation is $2.95 \%$, while that of FL-Smidth is $7.45 \%$; therefore, it is obvious that MGGP equation has a better performance than FL-Smidth equation to predict the burnability of clinker.

\section{Conclusions}

The burnability of two types of Portland clinker (PC1 and PC2) was investigated at different silica modules (SM) and lime saturation factors (LSF). The experimental data tests indicated that increase in the LSF and decrease in the SM cause reduction in clinker burnability. Consequently, a higher amount of free $\mathrm{CaO}$ (wt \%) of clinker is obtained. In addition, the results showed that the burnability of PC2 was more than that of PC1. Consequently, the PC2 with higher alumina module (AM) gave less amount of free $\mathrm{CaO}(\mathrm{wt} \%)$. Moreover, for the first time, the MGGP model was applied to predict the burnability of clinker, and the results of this model were in a good agreement with experimental data. A correlation based on MGGP model was introduced to predict the clinker burnability and its results were compared with FL-Smidth equation. It was shown that the performance of the MGGP to predict the experimental data is better than that of FL-Smidth equation. As a result, it seems that the MGGP model is an appropriate tool to predict the performance of clinker burning process.

\section{References}

[1] Herfort D., Moir G., Johansen V. et al.: Adv. Cem. Res, 2010, 22, 187. https://doi.org/10.1680/adcr.2010.22.4.187

[2] Hokfors B., Viggh E., Bostrom D., Backman R.: Adv. Cem. Res, 2015, 27, 50. https://doi.org/10.1680/adcr.13.00071

[3] Frigione G., Zenone F., Esposito M.: Cem. Concr. Res, 1983, 13, 483. https://doi.org/10.1016/0008-8846(83)90006-6

[4] Stephan D., Maleki H., Knofel D. et al.: Cem. Concr. Res, 1999, 29, 545. https://doi.org/10.1016/S0008-8846(99)00009-5

[5] Chen Y., Shin P., Chiang L. et al.: J. Hazard. Mater, 2009, 170,

443. https://doi.org/10.1016/j.jhazmat.2009.04.076

[6] Kolovos K., Barafaka S., Kakali G., Tsivilis S.: Ceramics-Silikaty, 2005, 49, 205.

[7] Ifka T., Palou M., Bazelvo Z.: Ceram-Silikaty, 2012, 56, 76.

[8] Ract P., Espinosa D., Tenorio J.: Waste Manage., 2003, 23, 281. https://doi.org/10.1016/S0956-053X(02)00061-2

[9] Kakali G., Parissakis G., Bouras D.: Cem. Concr. Res, 1996, 26, 1473. https://doi.org/10.1016/0008-8846(96)00143-3

[10] Kolovos K., Tsivilis G., Kakali G.: Cem. Concr. Res, 2002, 32, 463. https://doi.org/10.1016/S0008-8846(01)00705-0

[11] Ma X., Chen H., Wang P.: Cem. Concr. Res, 2010, 40, 1681 https://doi.org/10.1016/j.cemconres.2010.08.009

[12] Altun I.: Cem. Concr. Res, 1999, 29, 1847.

https://doi.org/10.1016/S0008-8846(99)00151-9
[13] Boughanmi S., Labidi I., Megriche A. et al.: Cem. Concr. Res, 2018, 105, 72. https://doi.org/10.1016/j.cemconres.2018.01.006

[14] Shang D., Wang M., Xia Z. et al.: Constr. Build. Mater., 2017, 146, 344. https://doi.org/10.1016/j.conbuildmat.2017.03.129

[15] Kolovos K., Tsivilis A., Kakali G.: J. Therm. Anal. Calorim., 2004, 77, 759. https://doi.org/10.1023/B:JTAN.0000041655.82776.09

[16] Zhao Y., Lu L., Wang S. et al.: J. Inorg. Organomet. P., 2013, 23, 930. https://doi.org/10.1007/s10904-013-9873-2

[17] Ghalandari V., Rafsanjani H.: Chem. Chem. Technol, 2019, 13, 205. https://doi.org/10.23939/chcht13.02.205

[18] Ghalandari V., Majd M., Golestanian A.: Energy, 2019, 173, 833. https://doi.org/10.1016/j.energy.2019.02.102

[19] Bagheri H., Mohebbi A.: Korean J. Chem. Eng, 2017, 34, 2686. https://doi.org/10.1007/s11814-017-0166-2

[20] Bagheri H., Ghader S.: Mol. Liq, 2017, 236, 172. https://doi.org/10.1016/j.molliq.2017.03.101

[21] Sheikhi-Kouhsar M., Bagheri H., Raeissi S.: Fluid Phase Equilibr., 2015, 395, 51. https://doi.org/10.1016/j.fluid.2015.03.005

[22] Bagheri H., Mansoori G., Hashemipour H.: J. Mol. Liq., 2018, 261, 174. https://doi.org/10.1016/j.molliq.2018.03.081

[23] Mohebbi A., Taheri M., Soltani A.: Int. J. Refrig., 2008, 31, 1317. https://doi.org/10.1016/j.ijrefrig.2008.04.008

[24] Bavdaz G., Kocijan J., Imeas T.: T. I. Meas. Control, 2007, 29, 17. https://doi.org/10.1177/0142331207070362

[25] Pani A., Vadlamudi V., Mohanta H.: ISA Transact., 2013, 52, 19. https://doi.org/10.1016/j.isatra.2012.07.004

[26] Kinnear Jr. K. (Ed.): Advances in Genetic Programming. MIT Press, Massachusetts 1994.

[27] Ghalandari V., Hashemipour H., Bagheri H: Fluid Phase Equilibr., 2020, 508, 112433.

https://doi.org/10.1016/j.fluid.2019.112433

[28] Esmaeili H., Hashemipour H.: J. Mol. Liq., 2018, 272, 692. https://doi.org/10.1016/j.molliq.2018.10.011

[29] Alsop P.: The Cement Plant Operations Handbook : For DryProcess Plants, $6^{\text {th }}$ edn. Tradeship Publications Ltd. 2014.

[30] Alemayehu F., Sahu O.: Adv. Mater., 2013, 2, 23. https://doi.org/10.11648/j.am.20130202.12

Received: October 28, 2019 / Revised: November 11, 2019 / Accepted: January 27, 2020

\section{ЕКСПЕРИМЕНТАЛЬНЕ ДОСЛІДЖЕННЯ І МОДЕЛЮВАННЯ МУЛЬТИГЕННОГО ГЕНЕТИЧНОГО ПРОГРАММУВАННЯ СПАЛЮВАННЯ ПОРТЛАНД-КЛІНКЕРУ}

Анотація. Вивчено вплив хімічного складу сировини на спалювання клінкеру внаслідок визначення вмісту вільного СаО (\% мас.) клінкеру. Досліджено спалювання двох типів портланд-клінкеру з силікатним модулем 2,3, 2,5 та 2,7 та коефіцієнтом насичення вапном 0,88-0,98. 3 використанням моделі мультигенного генетичного програмування (MGGP), прогнозовано спалювання клінкеру. Показано, щуо модель MGGP є прийнятною для прогнозування кількості вільного СаО (\% мас.), а для ї̈ точного розрахунку введено корелячію. Величину кореляиії порівняно з рівнянням FL-Smidth. Встановлено, щзо середні похибки кореляиії MGGP та рівняння FL-Smidth були 2,95 та 7,45 \% відповідно.

Ключові слова: мультигенне генетичне програмування, спалювання, вільний $\mathrm{CaO}$, портланд-клінкер, корелячія. 